\title{
Changes in flowering phenology of Cardamine concatenata and Erythronium americanum over 111 years in the Central Appalachians
}

\author{
Lori Petrauski · Sheldon F. Owen · George D. Constantz • James T. Anderson $\mathbb{D}$
}

Received: 8 November 2018/Accepted: 4 July 2019/Published online: 11 July 2019

(C) The Author(s) 2019

\begin{abstract}
Spring ephemerals in the Central Appalachians are a key component of deciduous forest communities and can be indicators of shifting phenology due to climate changes in this ecosystem. The objectives of this study were to (1) determine if there have been any changes in date of flowering for the Cutleaf Toothwort (Cardamine concatenata) and Yellow Trout Lily (Erythronium americanum) in West Virginia over the last 111 years; (2) determine which climatic factors affect the blooming date of these perennial, spring ephemeral wildflowers; and (3) evaluate the effect of elevation on changing blooming dates using herbarium specimens and photographs from 1904 to 2015. Both species are widespread throughout the woodlands of eastern North America. Both species have significantly advanced their spring flowering over the last century $(\bar{x}=0.91$ days $/ \mathrm{dec}-$ ade). Spring temperature was the strongest predictor of
\end{abstract}

Communicated by Paul M. Ramsay.

L. Petrauski · J. T. Anderson ( $\square)$

School of Natural Resources, West Virginia University, PO Box 6125, Morgantown, WV 26506, USA

e-mail: jim.anderson@mail.wvu.edu

S. F. Owen

West Virginia University Extension Service,

PO Box 6108, Morgantown, WV 26506, USA

G. D. Constantz

Capon Bridge, WV 26711, USA blooming date (2.91 and 3.44 days earlier $/{ }^{\circ} \mathrm{C}$ increase in spring temperature, respectively). Flowers at $<500 \mathrm{~m}$ elevation bloomed earlier and demonstrated a stronger shift in flowering date over time than flowers at $>1000 \mathrm{~m}$ elevations. Lower elevations, higher spring and winter temperatures, and low amounts of precipitation were associated with earlier spring flowering. This research demonstrates the plasticity of phenological response to a variety of climatic variables, the usefulness of using herbarium specimens to reconstruct flowering dates over a topographically variable area, and the contrasting effects of climate change on high elevation regions of West Virginia.

Keywords Blooming phenology $\cdot$ Herbarium specimens $\cdot$ Climate change $\cdot$ Historical phenology

\section{Introduction}

Climate affects the phenology of plants and animals, and changes in climate pose possible risks for phenological mismatches and shifts in vegetative communities (Memmott et al. 2007; Crimmins et al. 2008) if species cannot shift their distributions in synchrony with the changing climate (Ash et al. 2016). Flowering of herbaceous plants has been heavily studied due to the sensitivity of this phenophase to 
changes in climate (Gezon et al. 2016) and the fitness insights gained by studying the reproductive phase of plant life (Inouye 2008). Flowering phenology can be influenced by a number of abiotic factors, including increasing spring temperatures (Primack et al. 2004) [especially in the months before flowering (MillerRushing and Primack 2008)], spring precipitation (Matthews and Mazer 2016), elevation (Crimmins et al. 2011; Čufar et al. 2012), and snowmelt (Inouye 2008; Livensperger et al. 2016).

Geographic location, including elevation, is a strong contributing factor in the sensitivity of plant phenology (Matthews and Mazer 2016), due to its association with microclimates, which can influence temperature or the risk of frost damage (Inouye 2008). Elevation has an effect on the strength of phenology shifts in horse-chestnut trees Aesculus hippocastanum L. (Defila and Clot 2001), and changes in climate affect phenology to a greater degree in higher elevations than lower elevations in Slovakia (Čufar et al. 2012). In the Himalayas, flowers were found to bloom an average of 26 days earlier per $1000 \mathrm{~m}$ decrease in elevation (Gaira et al. 2011). Due to a warming climate, plants are able to expand their range and grow at higher elevations (Lenoir et al. 2008), which can affect the way these species respond to changes in climate. However, there can be confounding factors involved with shifting ranges such as precipitation or moisture availability. For example, Crimmins et al. (2011) found that plants in California shifted to lower elevations despite increases in temperature, due to decreased water availability in higher elevations. Geographic location also includes latitude, which can give insight into larger patterns of phenology (McKinney et al. 2012). For example, the phenology of species in higher latitudes in the northern hemisphere and lower latitudes in the southern hemisphere is more strongly affected by changes in climate than latitudes closer to the equator (Guyon et al. 2011). Therefore, it is important to examine latitude in conjunction with elevation as factors influencing phenological shifts.

Studies in the eastern United States have shown shifts of flowering times, ranging from an average of 7 days earlier since the 1850s in Concord, Massachusetts (Miller-Rushing and Primack 2008) to an average of 2.4 days earlier since the 1970s in Washington, DC (Abu-Asab et al. 2001). The strongest predictor of spring flowering phenology has been temperature (Jackson 1966; Beaubien and Freeland 2000; Primack et al. 2004; Miller-Rushing and Primack 2008), which covaries with other environmental factors such as snowmelt (Inouye 2008) and elevation (Gaira et al. 2011). Warmer winter temperatures have been linked to earlier flowering dates for a diversity of herbaceous and woody plant species (Beaubien and Freeland, 2000; Miller-Rushing and Primack 2008) and increased precipitation has been associated with later flowering of spring ephemerals such as western trilliums Trillium ovatum Pursh (Matthews and Mazer 2016).

Benefits of earlier spring blooming could include high levels of light and moisture and less interspecific competition for pollinators (Forrest and Thomson 2010). However, there may also be consequences associated with earlier flowering, such as frost damage leading to decreased reproductive fitness (Gezon et al. 2016). Past studies found that flowering times respond to increases in spring temperatures by advancing their date of flowering by 3.07 days (Miller-Rushing and Primack 2008), 3.39 days (Park and Schwartz 2015), 3.6 days (Primack et al. 2004), and 6 days (Robbirt et al. 2011) per $1{ }^{\circ} \mathrm{C}$ increase in spring temperature.

Spring ephemeral wildflowers, which are especially sensitive to changes in climate, have served as useful indicators of phenological advancement (Fitter et al. 1995). For example, spring ephemerals emerge shortly after snowmelt (Lapointe 2001), and earlier snowmelt has been linked to earlier flowering (Lambert et al. 2010). Winter temperatures and precipitation (Matthews and Mazer 2016) have also been used to analyze flowering phenology of spring perennials. Most studies of flowering phenology are constrained by a lack of long-term historical data (Primack et al. 2004; Robbirt et al. 2011). This is why herbarium specimens and photographs have been explored as a way to reconstruct historical phenology of spring ephemerals and other flowering plants (Lavoie and Lachance 2006; Miller-Rushing et al. 2006; Gaira et al. 2011; Calinger et al. 2013; Everill et al. 2014). Miller-Rushing et al. (2006) and Robbirt et al. (2011) determined that herbarium specimens alone can successfully show flowering response of a variety of flowering plants to changing climate.

The three objectives of this study were to (1) determine if there have been changes in date of flowering for two species of spring ephemerals in West Virginia over the last 111 years, (2) evaluate 
which climatic and non-climatic factors affect their blooming dates, and (3) evaluate the effect of elevation on changing blooming dates. It is important to study the factors that shift phenology because any phenophases that are altered can disrupt species interactions. We predicted that spring ephemerals have shifted their flowering dates over the last century in response to changes in climate, especially increased spring temperature, and that flowers at higher elevations would flower later than flowers at low elevations.

\section{Methods}

Study area

West Virginia is a heavily forested, mountainous state located in the Appalachian region of the United States. Temperature, elevation, and precipitation differ considerably throughout the state. The average statewide yearly temperature is $6-17\left({ }^{\circ} \mathrm{C}\right)$, where the lower southern regions are warmer than the mountainous regions. The average elevation is $457 \mathrm{~m}$ with the highest point (Spruce Knob) at $1482 \mathrm{~m}$ and the lowest point (Harper's Ferry) at $149 \mathrm{~m}$ above sea level. Annual precipitation ranges between 81 and $132 \mathrm{~cm}$ statewide. West Virginia is $79 \%$ forested and the forests are 94\% deciduous hardwoods. Oak-hickory forest type covers $74 \%$ of West Virginia forestlands followed by northern hardwood forest type (18\%) (Morin et al. 2013). West Virginia is partially composed of hemlock forests, and boreal and red spruce forests in high elevations.

\section{Study species}

Cutleaf Toothwort Cardamine concatenata (Michx.) Sw. (Brassicacae) and Yellow Trout Lily Erythronium americanum Ker Gawl. (Liliaceae) are both common spring wildflowers in eastern North America (Strausbaugh and Core 1978). Their short blooming-window (1-2 weeks) makes them good candidates for phenology research (Shetler and Wiser 1987; Lapointe 2001). Both species are native perennial herbs that grow in moist bottomland and deciduous forests. Spring ephemerals are among the first plants to flower in the spring. The specific phenophase used for this study was "open flowers" (USA-NPN 2012). For this study, plants with $\geq 50 \%$ of all fresh flowers in bloom were used, which is easily observed in herbarium specimens and pictures.

\section{Observations}

We used herbarium specimens and dated photographs to identify locations and flowering dates for $C$. concatenata and $E$. americanum in West Virginia. Herbarium specimens or photographs that showed at least half of the flowers open on a plant were scored as peak-flowering (Primack et al. 2004; Primack and Miller-Rushing 2012). Specimens were processed at six public herbariums, including five in West Virginia and one in Pennsylvania, and the personal herbarium of a West Virginian citizen (Table 1). To obtain elevation data and accurate climatic data, locations of observations were mapped using ArcGIS Version 10.3 using the location descriptions on the herbarium specimens (Fig. 1). A West Virginia citizen contributed 11 dated photographs with known locations (2005-2015), which were added to the herbarium dataset to supplement the recent observations. Each usable herbarium specimen and photograph included date and location. Specimens without locality data or with overly broad localities (i.e., county only) were excluded from the study. Overall, the observations gained from these specimens reflect an average flowering date because each specimen is not necessarily a first or last flowering observation. By using average flowering dates of species with short blooming windows, our conclusions will more accurately represent the shifts and changing phenology of these species as compared to first flowering dates (CaraDonna et al. 2014).

\section{Climate}

Climate data at 13 stations in West Virginia were recorded by the US Historical Climatology Network (Williams et al. 2007) since 1890. A series of estimation maps was made for each decade (12 decades 1890-2014) using the Radial Basis Function interpolation method in ArcGIS Version 10.3. These decadal interpolations were used to estimate average decadal yearly temperature, spring and winter temperatures, and spring precipitation for each flowering observation. Radial basis functions create surfaces of estimated measurements based on the degree of smoothing from measured points, resulting in an exact 
Table 1 Sources of flowering data for Cardamine concatenata and Erythronium americanum in West Virginia, USA over the last 111 years

\begin{tabular}{|c|c|c|c|c|}
\hline \multirow[t]{2}{*}{ Source } & \multicolumn{2}{|l|}{ Number of records } & \multirow[t]{2}{*}{ City } & \multirow[t]{2}{*}{ Dates } \\
\hline & Cardamine concatenata & Erythronium americanum & & \\
\hline Fairmont State University Herbarium & 1 & 10 & Fairmont, WV & $1963-1981$ \\
\hline Marshall University Herbarium & 72 & 61 & Huntington, WV & 1928-2001 \\
\hline University of Charleston Herbarium & 0 & 1 & Charleston, WV & 1968 \\
\hline West Virginia University Herbarium & 63 & 58 & Morgantown, WV & 1904-2013 \\
\hline George B. Rossbach Herbarium & 17 & 20 & Buckhannon, WV & 1929-1999 \\
\hline Carnegie Museum of Natural History & 11 & 6 & Pittsburgh, PA & $1930-1988$ \\
\hline Personal Herbarium & 1 & 1 & Old Fields, WV & 2013 \\
\hline Personal Photograph Collection & 5 & 6 & Morgantown, WV & 2005-2015 \\
\hline
\end{tabular}

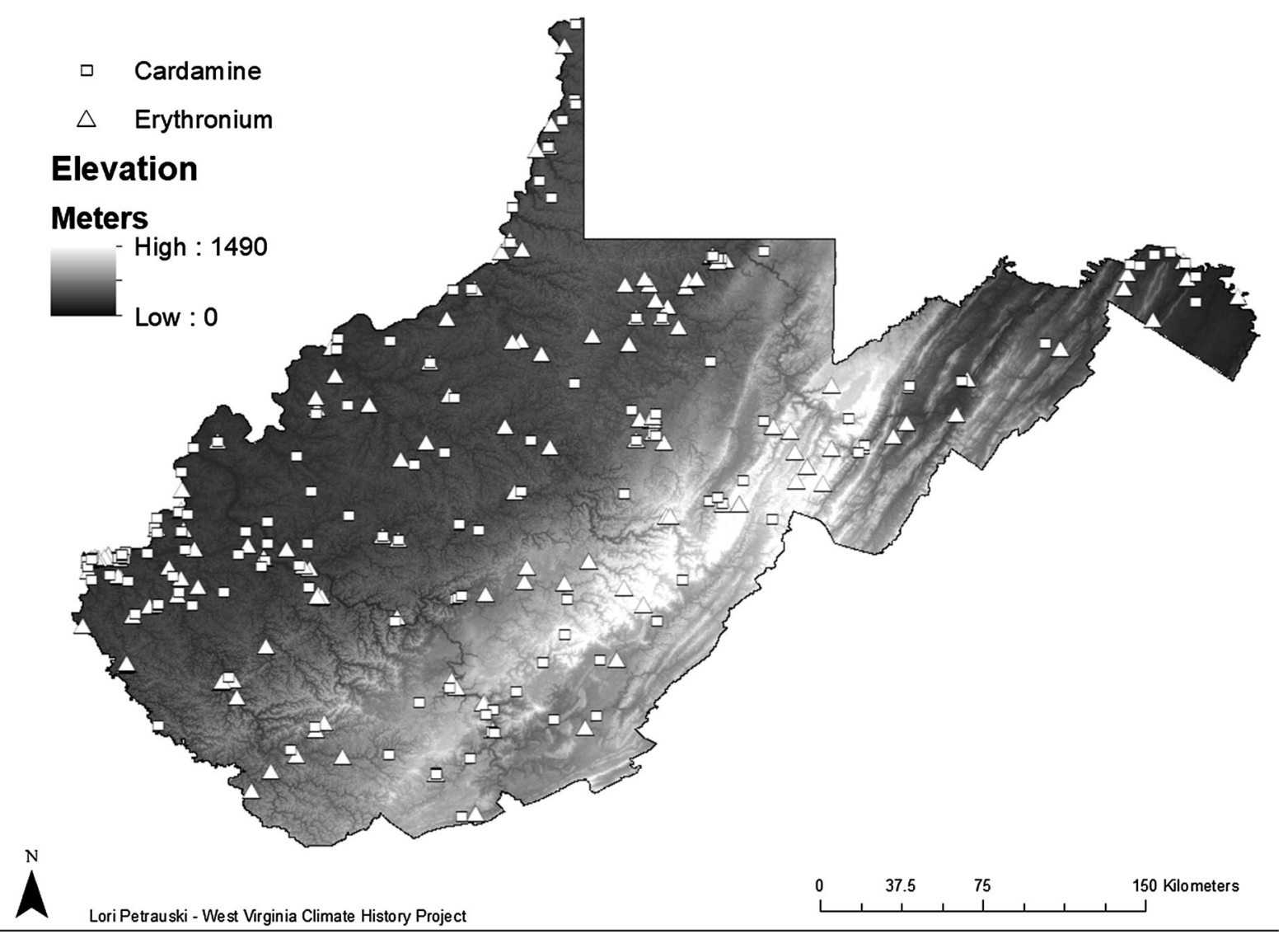

Fig. 1 Collection locations of Cardamine concatenata and Erythronium americanum herbarium specimens collected from 1904-2015 in West Virginia, USA

interpolation, which qualifies it as a suitable method for determining unknown atmospheric values based on known neighboring measurements (Apaydin et al. 2004; Ashiq et al. 2010). 
Data analyses

The wildflowers dataset included day of the year (Julian calendar), year, elevation, average decadal spring temperature, average decadal spring precipitation, average decadal winter temperature, average decadal yearly temperature, and species. All variables were normally distributed except elevation, which was $\log$ transformed. Correlation and regression were used to test for collinearity of the variables. Yearly temperature was highly correlated with spring temperature $(r=0.86)$ and with winter temperature $(r=0.85)$, and therefore was not used in analyses (Miller-Rushing and Inouye 2009).

To test for changes in flowering date, the dates of flowering for each species were regressed against year. A Welch's $t$ test, which is robust to unequal variances and sample sizes (Ruxton 2006), was used to determine if there was a difference between historical and current flowering dates. Historical flowering dates were considered to be before 1970 and current dates were considered the years 1970 and after, when global surface temperatures began to steadily increase (IPCC 2014).

Observations were divided into several elevation categories (low: under $500 \mathrm{~m}$, mid: $500-1000 \mathrm{~m}$, high: above $1000 \mathrm{~m}$ ) and the day of flowering was regressed against year for each category to compare the difference in magnitude of phenology shifts as a function of elevation. A one-way Analysis of Variance (ANOVA) was used to test for differences in flowering date among the elevation categories.

\section{Results}

Changes in climate

Between 1970 and 2014, average spring temperatures (March-April) in West Virginia increased 10 times as much as they did between 1890 and 1969, and spring temperatures between 1970 and $2014\left(\bar{x}=8.52{ }^{\circ} \mathrm{C}\right.$, $\mathrm{SE}=0.18)$ were significantly higher than between 1890 and $1969\left(\bar{x}=8.08{ }^{\circ} \mathrm{C}, \mathrm{SE}=0.16\right)\left(t_{103}=-\right.$ $1.77, P=0.03)$. Over the 125 years of weather data, the average climate variables have mostly remained constant when analyzed over the entire state (Fig. 2). Spring precipitation, spring temperature, and winter temperature have only increased slightly (precipitation increasing $0.030 \mathrm{~cm} /$ decade; spring temperature increasing $0.055^{\circ} \mathrm{C} / \mathrm{decade}$; winter temperature increasing $0.003{ }^{\circ} \mathrm{C} /$ decade) since 1890 . However, variation in temperature and precipitation exists within West Virginia and change over time is evident in some parts of the state more than others for spring temperature (Fig. 3a), winter temperature (Fig. 3b), and spring precipitation (Fig. 3c). For example, spring and winter temperatures have especially increased in the Eastern Panhandle region of West Virginia as compared to the rest of the state, and precipitation has increased throughout the state.

Changes in flowering phenology

Overall, there were 337 observations of flowering, including 170 for $C$. concatenata and 167 for $E$. americanum between 1904 and 2015 (Table 2). Across historic and contemporary dates, the flowering dates were significantly different $\left(t_{277.75}=4.52, P<0.001\right)$ between $C$. concatenata $(\bar{x} \pm \mathrm{SD}=102$ (April 12) \pm 12.3 days, $\mathrm{SE}=0.946)$ and E. americanum $(\bar{x} \pm \mathrm{SD}=101$ (April 11) \pm 7.5 days, $\mathrm{SE}=0.643$ ), and therefore analyzed separately. Normality was confirmed for flowering dates of $C$. concatenata $(W=0.987, \quad P=0.135) \quad$ and $E$. americanum ( $W=0.994, P=0.784)$ using Shapiro-Wilk tests. $C$. concatenata and E. americanum have both significantly advanced their spring flowering over the last century (Fig. 4). C. concatenata $\left(F_{1},{ }_{168}=5.76\right.$, $P=0.017)$ has flowered 0.87 days earlier each decade, and E. americanum $\left(F_{1,165}=9.78\right.$, $P=0.002)$ has flowered 0.94 days earlier every decade. For both species, there was a significant difference between historical $(\bar{x} \pm \mathrm{SD}=108$ (April 18) \pm 11.8 days, $\mathrm{SE}=0.244)$ flowering dates and current $(\bar{x} \pm \mathrm{SD}=102$ (April 12) \pm 10.0 days, $\mathrm{SE}=$ 0.722 ) flowering dates based on Welch's $t$ tests. $C$. concatenata flowered significantly earlier $\left(t_{155}=3.07, P=0.002\right)$ in recent years $(\bar{x} \pm \mathrm{SD}=99$ (April 9) \pm 11.7 days, $\mathrm{SE}=1.20$ ) as compared to pre-1970 ( $\bar{x} \pm \mathrm{SD}=105$ (April 15) \pm 12.4 days, $\mathrm{SE}=1.43$ ), and $E$. americanum also significantly advanced $\left(t_{111}=3.66, P<0.001\right)$ its current flowering $(\bar{x} \pm \mathrm{SD}=105$ (April 15) \pm 7.5 days, $\mathrm{SE}=$ $0.75)$ as compared to historical records $(\bar{x} \pm \mathrm{SD}=$ 110 (April 20) \pm 10.9 days, $\mathrm{SE}=1.34)$. Normality was confirmed using a Shapiro-Wilk test (C. concatenata: historical: $W=0.98, \quad P=0.41$, current: 
A

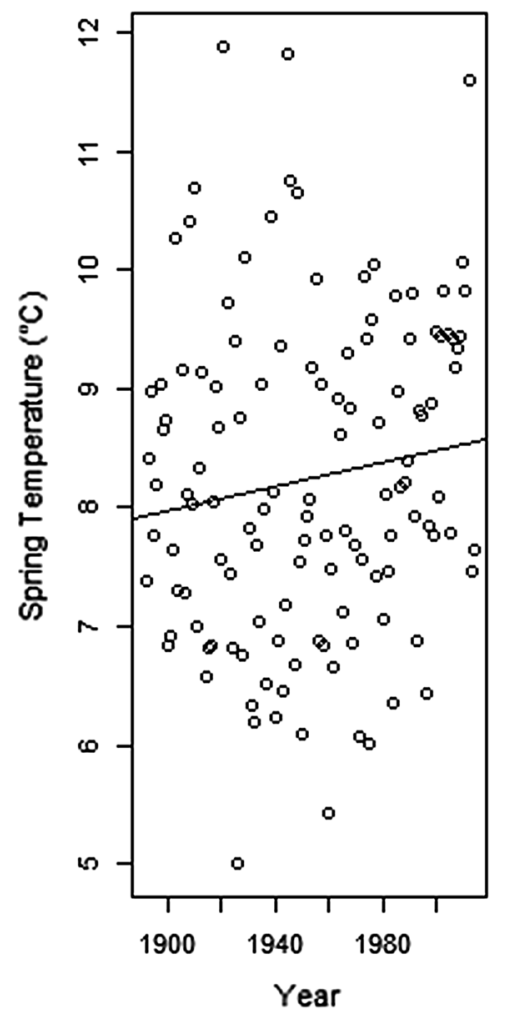

B

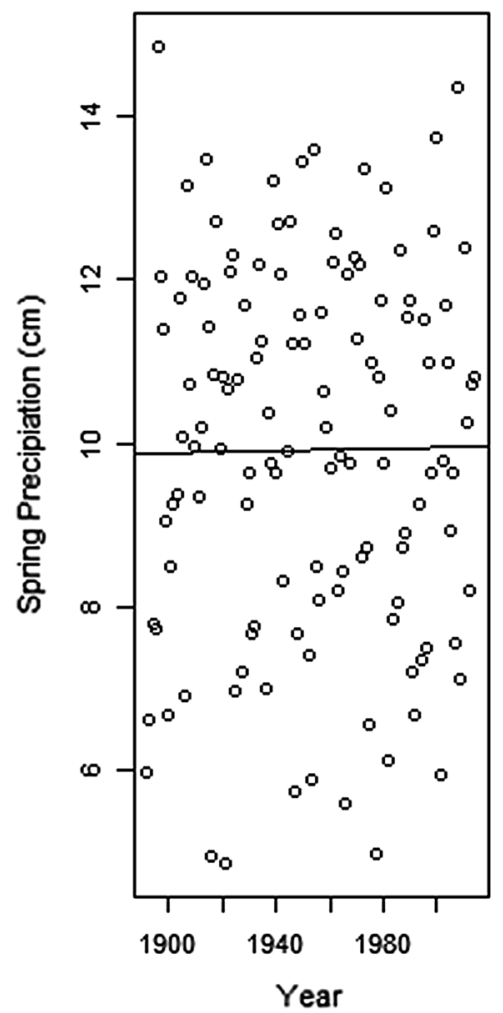

C

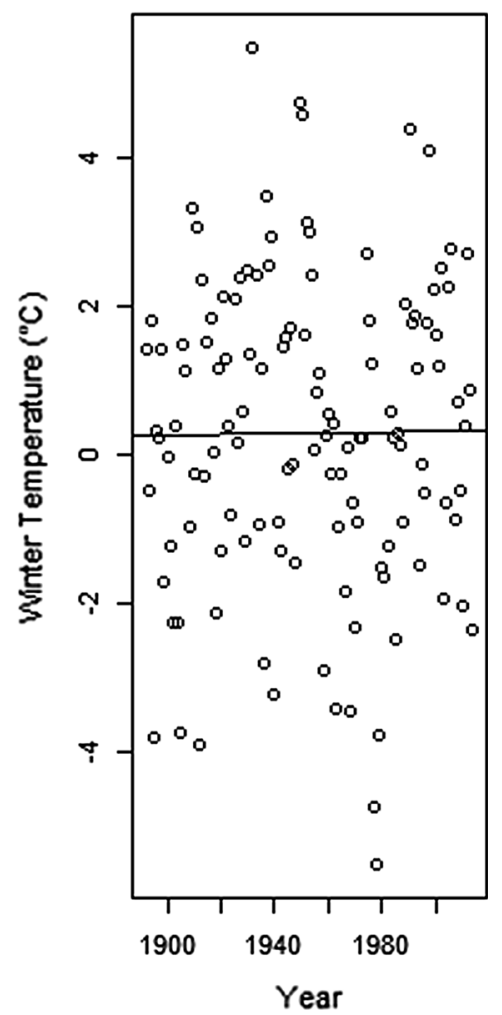

Fig. 2 Average climate in West Virginia, USA over 125 years (1890-2014). a Spring temperature is average March-April temperatures, b spring precipitation is average March-April rainfall, and $\mathbf{c}$ winter temperature is average January-February temperature based on 13 United States Historical Climatology Network recording stations located in West Virginia
A

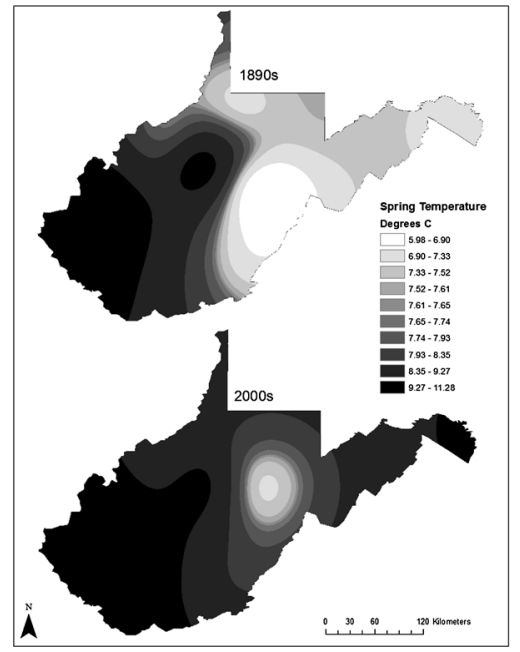

B

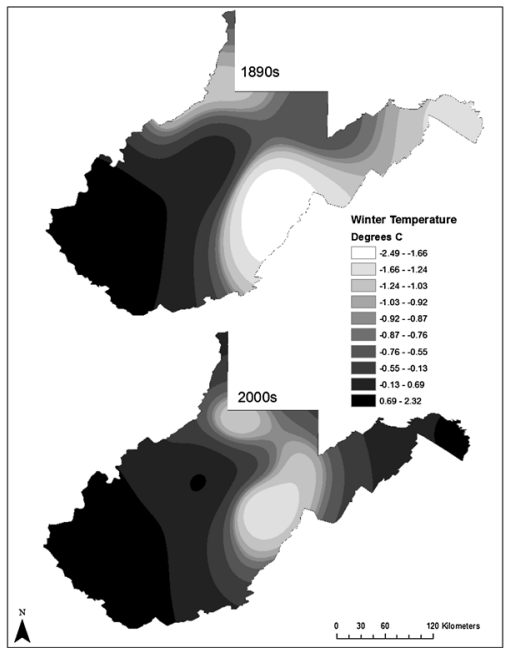

C

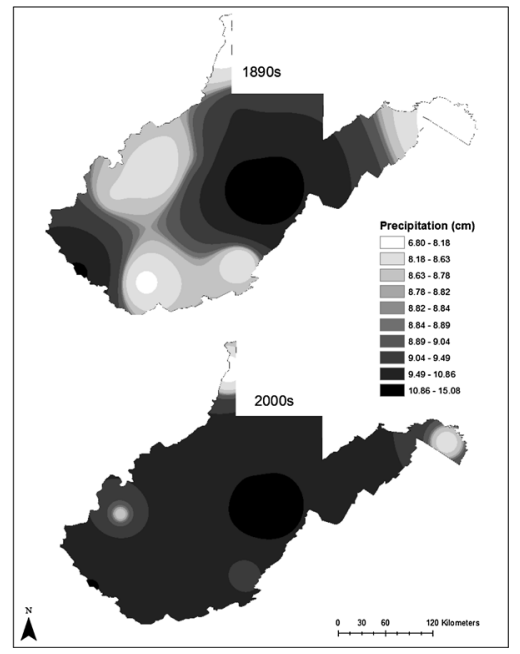

Fig. 3 a Spring temperature (March-April), b Winter temperature (January-February), c Spring precipitation (March-April) interpolations in West Virginia, USA from the $1890 \mathrm{~s}$
(1890-1899) and 2000s (2000-2014). Interpolations are based on climate data from 13 United States Historical Climatology Network recording stations located in West Virginia 
Table 2 Observations of Cardamine concatenata and Erythronium americanum categorized by year from West Virginia, USA

\begin{tabular}{lcc}
\hline Year of observation & \multicolumn{2}{l}{ Species } \\
\cline { 2 - 3 } & Erythronium americanum & Cardamine concatenata \\
\hline $1904-1921$ & 0 & 3 \\
$1922-1929$ & 6 & 6 \\
$1930-1959$ & 42 & 57 \\
$1960-1989$ & 82 & 58 \\
$1990-2015$ & 37 & 46 \\
Total & 167 & 170 \\
\hline
\end{tabular}

Fig. 4 Flowering dates of a $C$. concatenata $(y=-$ $0.088 x+275.53$, $\left.R^{2}=0.02, P=0.017\right)$ and b E. americanum $(y=-$ $0.094 x+292.76$, $\left.R^{2}=0.05, P=0.002\right)$ in West Virginia, USA from 1904 to 2015
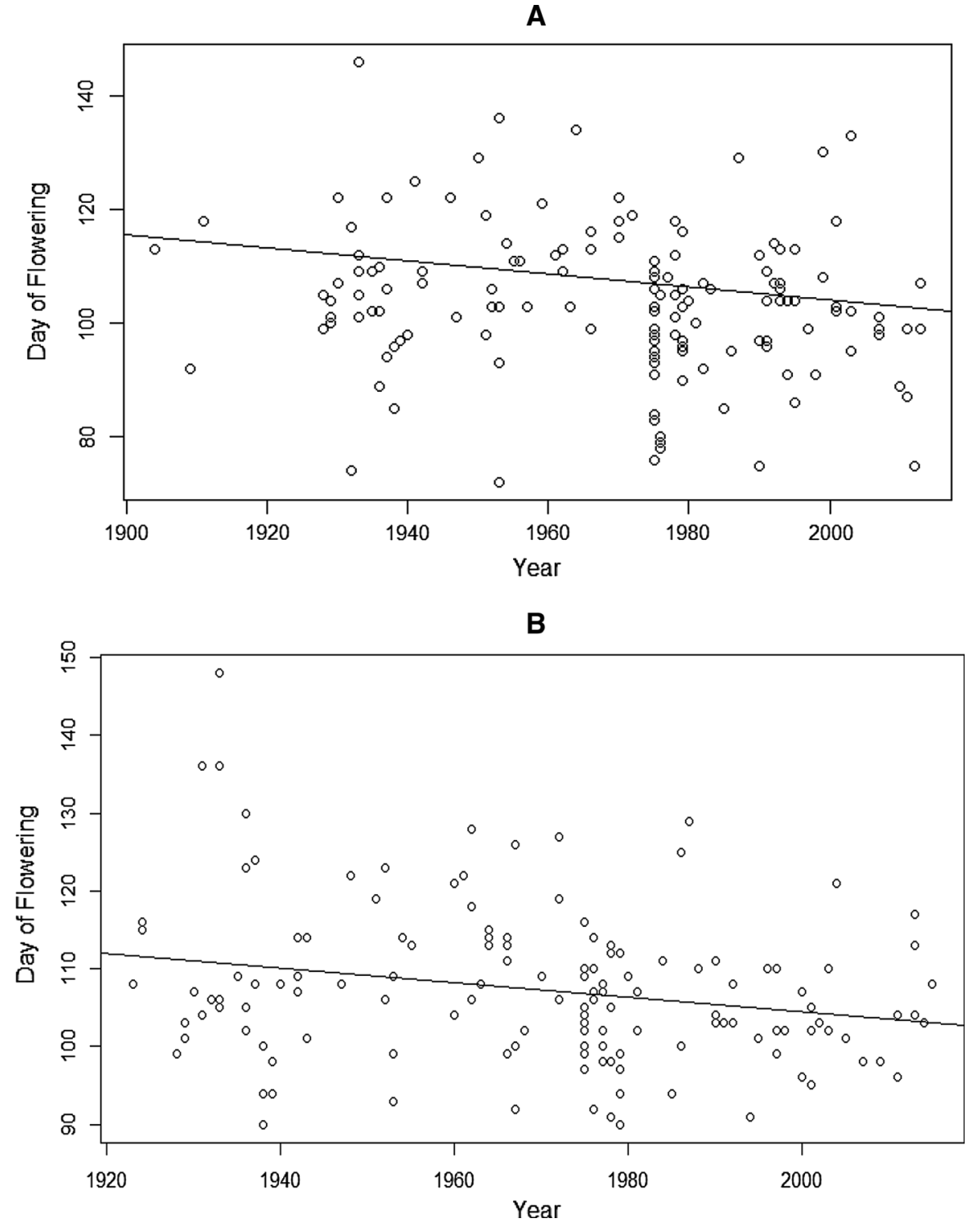
$W=0.99, \quad P=0.74 ; \quad E$. americanum: historical: $W=0.98, P=0.48$, current: $W=0.98, P=0.26$ ).

\section{Elevation effects}

Climate variables and elevation had differing effects on the date of flowering for each species, as determined using simple linear regressions (Table 3 ). Given that elevation was log transformed, for every $277.5 \mathrm{~m}$ (10\% of total elevation range) increase in elevation, $C$. concatenata flowered 0.5 days later $(\mathrm{SE}=1.81)$ $\left(F_{1,168}=8.55, P=0.004\right)$ and $E$. americanum flowered 0.72 days later $(\mathrm{SE}=1.34) \quad\left(F_{1,165}=9.72\right.$, $P=0.002$ ) for every $124.1 \mathrm{~m}$ increase in elevation. In other terms, for every $1000 \mathrm{~m}$ increase in elevation, C. concatenata flowered 1.80 days later and $E$. americanum flowered 5.8 days later.

There was a significant difference in flowering dates depending on elevation $\left(F_{1,335}=28.74\right.$, $P<0.001)$. Flowers at low elevations $(n=267)$ bloomed earlier $(\overline{\mathrm{x}} \pm \mathrm{SD}=104 \quad$ (April 14) \pm 10.6 days, $\mathrm{SE}=0.651)$ as compared to mid elevations $\quad(n=52, \quad \overline{\mathrm{x}} \pm \mathrm{SD}=108 \quad$ (April 18) \pm 12.2 days, $S E=1.953)$ and high elevations $(n=18, \overline{\mathrm{x}} \pm \mathrm{SD}=117$ (April 27) \pm 9.1 days, $\mathrm{SE}=$ 2.143). Flowers at low elevations demonstrated a stronger shift toward earlier flowering dates over time (0.95 days earlier each decade) than flowers at mid (0.68 days earlier each decade) or high elevations (1.32 days later each decade). Normality was confirmed for low $(W=0.994, \quad P=0.311)$, mid ( $W=0.978, \quad P=0.647)$, and high $(W=0.980$, $P=0.950)$ elevations using a Shapiro-Wilk test and equal variances were confirmed using a KolmogorovSmirnov test $(D=0.156, P=0.373)$.
Climatic variables

Precipitation, spring temperature, and winter temperature had varying effects on the flowering of $C$. concatenata and E. americanum (Fig. 5). C. concatenata flowered 2.91 days earlier $(\mathrm{SE}=0.82)$ $\left(F_{1,168}=12.51, P<0.001\right)$ and $E$. americanum flowered 3.44 days earlier $(\mathrm{SE}=0.67)\left(F_{1,165}=31.40\right.$, $P<0.001)$ for each $1{ }^{\circ} \mathrm{C}$ increase in spring temperature. $C$. concatenata flowered 1.57 days earlier $(\mathrm{SE}=0.76)\left(F_{1,168}=4.28, P=0.040\right)$ and $E$. amer icanum flowered 1.11 days earlier $(\mathrm{SE}=0.51)$ $\left(F_{1,165}=4.82, P=0.029\right)$ for each $1{ }^{\circ} \mathrm{C}$ increase in winter temperature. Precipitation had no significant effect on $C$. concatenata's flowering dates, but $E$. americanum flowered 2.96 days later $(\mathrm{SE}=0.69)$ $\left(F_{1,165}=18.45, P<0.001\right)$ for every $1 \mathrm{~cm}$ increase in precipitation. Interactions among variables were investigated with no significant effects $(P>0.05)$.

\section{Discussion}

Overall, the flowering of E. americanum and $C$. concatenata advanced over the last 111 years and the flowers are blooming earlier than they did historically. Erythronium americanum advanced its spring flowering by an average of 6 days and was more sensitive to elevation, spring temperature, and spring precipitation than $C$. concatenata, which has also advanced an average of 6 days. Cardamine concatenata was slightly more affected by warmer winter temperatures. Lower elevations, higher spring temperatures, higher winter temperatures, and low amounts of precipitation were associated with earlier spring flowering overall.

Table 3 Statistically significant flowering responses of Cardamine concatenata and Erythronium americanum to increases in climatic variables and elevation from 1904-2015 in West Virginia, USA

\begin{tabular}{lrr}
\hline Climatic variable & Species & \\
\cline { 2 - 3 } & Erythronium americanum & Cardamine concatenata \\
\hline Spring Temperature $\left(+1^{\circ}\right.$ & 3.44 days earlier $(\mathrm{SE}=0.67)$ & 2.91 days earlier $(\mathrm{SE}=0.82)$ \\
Winter Temperature $\left(+1^{\circ}\right)$ & 1.11 days earlier $(\mathrm{SE}=0.51)$ & 1.57 days earlier $(\mathrm{SE}=0.76)$ \\
Precipitation $(+1 \mathrm{~cm})$ & 2.96 days later $(\mathrm{SE}=0.69)$ & No sig. effect \\
Elevation $(+1000 \mathrm{~m})$ & 5.8 days later $(\mathrm{SE}=11.90)$ & 1.80 days later $(\mathrm{SE}=5.61)$ \\
\hline
\end{tabular}



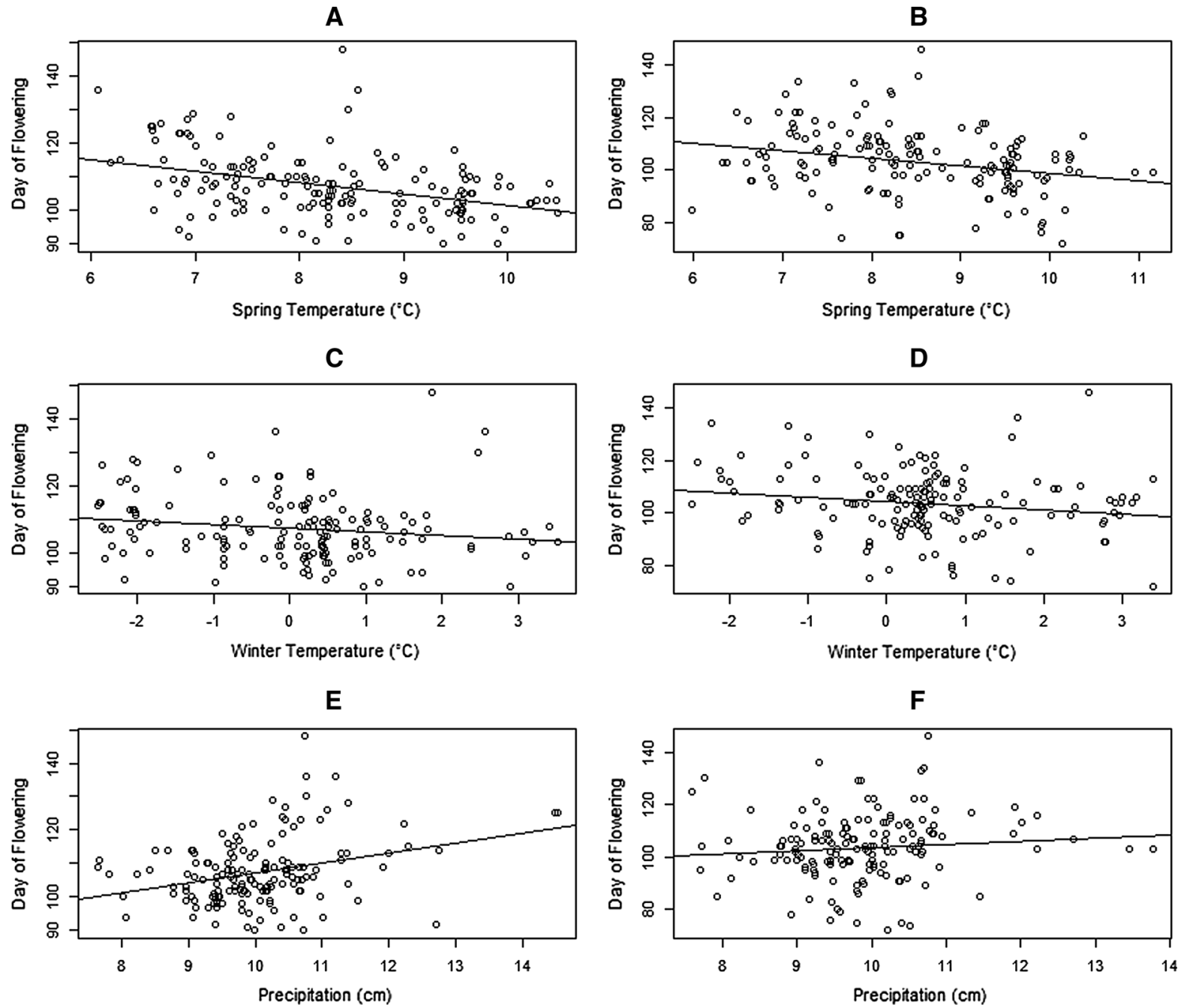

Fig. 5 Flowering responses of Cardamine concatenata and Erythronium americanum to increases in spring temperature from 1922 to 2015 in West Virginia, USA. Flowering of $E$. americanum in response to a spring temperature $(y=-$ $\left.3.44 x+135.83, \mathrm{R}^{2}=0.15, P<0.001\right)$ c winter temperature $\left(y=-1.11 x+107.3, R^{2}=0.02, P=0.03\right)$, and e precipitation

$\left(y=2.96 x+77.50, R^{2}=0.10, P<0.001\right)$. Flowering of $C$. concatenata in response to $\mathbf{b}$ spring temperature $(y=-$ $\left.2.91 x+127.87, R^{2}=0.06, P<0.001\right)$ d winter temperature $\left(y=-1.57 x+104.05, R^{2}=0.02, P=0.04\right)$, and f precipitation $\left(y=1.20 x+91.24, R^{2}=0.003, P=0.22\right)$

Spring precipitation only affected the flowering of $E$. americanum, an effect supported by previous research (Matthews and Mazer 2016). Years with higher spring precipitation and lower spring temperatures were associated with later flowering dates.

One of the major drivers of phenological studies is the risk of phenological mismatch (Root et al. 2003), which can occur when one species advances (Kudo and Ida 2013) or delays (Gezon et al. 2016) its phenology in relation to interacting species. For example, early-blooming spring ephemerals may

incur lower reproductive success due to a difference in phenological response by their pollinators (Rafferty and Ives 2011; Kudo and Ida 2013). However, for Claytonia lanceolate Pall. ex Pursh, another spring ephemeral, the rate of pollinator visits was higher for plants that flowered early, but not so early that they were threatened by frost (Gezon et al. 2016). In this case, the spring ephemeral balanced environmental and species interaction constraints for optimal flowering date. 
In general, it is thought that earlier blooming due to increased temperatures is beneficial for the plant's reproductive success (Elzinga et al. 2007) partly due to increased pollinator visits (Rafferty and Ives 2011); however, there is some disparity in the literature depending on the pollinator. For example, in Japan, spring ephemerals that bloomed earlier due to increasing temperatures differed in their reproductive success (seed production) based on their pollinators (Kudo et al. 2004) — the seed-set of bee-pollinated ephemerals drastically decreased, whereas fly-pollinated ephemerals experienced no change in their seed production due to the earlier blooming.

Earlier blooming caused by earlier spring onset has been linked to fewer pollinator visits (Petanidou et al. 2014) and a phenological mismatch in the emergence of pollinator bees, which resulted in decreased reproductive success for the spring ephemerals that relied on bees for pollination (Kudo and Ida 2013). Although generalist pollinators do occur in early spring within temperate deciduous forest communities (Motten 1986), C. concatenata is primarily pollinated by bees and $E$. americanum is pollinated by ants, so perhaps $C$. concatenata receives more severe consequences and less reproductive benefits for earlier blooming than $E$. americanum, which could help explain why E. americanum is advancing spring flowering more than $C$. concatenata. However, data to support this hypothesis are lacking, but this premise could serve as a starting point for a future research project on pollinator response to phenology change for spring ephemerals in the region.

Elevation had a strong effect on the flowering of these species. Flowers at $<500 \mathrm{~m}$ elevation bloomed earlier in the spring and advanced their flowering dates over time more than flowers at mid (500-1000 m) and high $(>1000 \mathrm{~m}$ ) elevations. In addition, the flowers found at $>1000 \mathrm{~m}$ in elevation have flowered later over time, which could be attributed to varying effects of climate change on high elevation areas as compared to low elevations. This suggests that wildflower communities at different elevations will be affected differently by changing climate. The high elevation areas of West Virginia also were the areas that experienced the least amount of climatic changes over the last century (Fig. 3), which would explain the lack of earlier flowering in high elevation species.

Our large statewide study area could harbor possible bias in imprecise geographic locations for flowering observations. Given that the location information on the herbarium specimens was not always exact, factors such as hillshade and aspect, which have been shown to explain variation in flowering phenology (Jackson 1966), could serve as confounding variables. However, we did exclude specimens that had broad localities such as county only to reduce some of this bias. Moreover, the high number of flowering observations can overcome potential sampling bias (Primack et al. 2004).

There are several issues associated with using herbarium specimens to understand phenology. Because the timing of phenophases is highly related to climate, and climatic conditions vary over sampling areas, it is difficult to compare the phenophases of specimens collected over large geographic areas (Lavoie and Lachance 2006). In addition to climatic differences, there is also uncertainty in determining exact full-flowering dates. Depending on the species, the time when an individual plant could be considered "full flowering" could range over several weeks, which could decrease the reliability of the data (Miller-Rushing et al. 2006). By choosing spring ephemeral species with short blooming windows, this risk was mitigated.

Another bias to consider is that of the original collectors of the herbarium specimens. Factors such as proximity to trails and roadways could have affected the geographic distribution of the observations (Miller-Rushing et al. 2006). However, based on the map of observations (Fig. 1), the distribution of the herbarium specimens used in this study is fairly uniform throughout the state.

Based on their advancing flowering dates, $C$. concatenata and E. americanum are at risk for phenological mismatches, including pollinator interactions and other species that may rely on the phenophases of these flowers, such as Pieris virginiensis (the West Virginia white butterfly). This research demonstrates the plasticity of phenological response to a variety of climatic variables, the usefulness of using herbarium specimens to reconstruct flowering dates over a topographically variable area, and the contrasting effects of climate change on high elevation regions of West Virginia. As a key component in deciduous forest communities, spring ephemerals in West Virginia are valuable indicators of shifting phenology in this ecosystem. 
Acknowledgements The authors thank many people who contributed observations and access to data: Carnegie Museum of Natural History, West Virginia University Herbarium, Fairmont State University Herbarium, University of Charleston Herbarium, George B. Rossbach Herbarium, Marshall University Herbarium, David Smaldone (Resource Recreation and Tourism, West Virginia University), and Andrew Walker (West Virginia University). We also thank Thomas Rodd (Friends of Blackwater) and Greg Good (Center for History of Physics, American Institute of Physics) for ideas and logistics. Funding and logistical support was provided by the U.S. Department of Agriculture Northeast Climate Hub (Grant 14-JV-11242306-094), the West Virginia Humanities Council (Grant 14086), and the West Virginia University Natural History Museum. J. T. Anderson was supported by the National Science Foundation under Cooperative Agreement No. OIA-1458952, the USDA National Institute of Food and Agriculture, McIntire Stennis project WVA00117, and the West Virginia Agricultural and Forestry Experiment Station during manuscript preparation. This is manuscript number 3360 of the West Virginia University Agriculture and Forestry Experiment Station, Morgantown.

Open Access This article is distributed under the terms of the Creative Commons Attribution 4.0 International License (http:// creativecommons.org/licenses/by/4.0/), which permits unrestricted use, distribution, and reproduction in any medium, provided you give appropriate credit to the original author(s) and the source, provide a link to the Creative Commons license, and indicate if changes were made.

\section{References}

Abu-Asab M, Peterson P, Shetler S, Orli S (2001) Earlier plant flowering in spring as a response to global warming in the Washington, DC, area. Biodivers Conserv 10:597-612

Apaydin H, Sonmez F, Yildirim Y (2004) Spatial interpolation techniques for climate data in the GAP region in Turkey. Climate Res 28:31-40

Ash J, Givnish T, Waller D (2016) Tracking lags in historical plant species' shifts in relation to regional climate change. Glob Change Biol 23:1305-1315

Ashiq M, Zhao C, Ni J, Akhtar M (2010) GIS-based high-resolution spatial interpolation of precipitation in mountainplain areas of Upper Pakistan for regional climate change impact studies. Theor Appl Climatol 99:239-253

Beaubien E, Freeland H (2000) Spring phenology trends in Alberta, Canada: links to ocean temperature. Int J Biometerol 44:53-59

Calinger K, Queenborough S, Curtis P (2013) Herbarium specimens reveal the footprint of climate change on flowering trends across north-central North America. Ecol Lett 16:1037-1044

CaraDonna P, Iler A, Inouye D (2014) Shifts in flowering phenology reshape a subalpine plant community. Proc Natl Acad Sci USA 111:4916-4921

Crimmins T, Crimmins M, Bertelsen D, Balmat J (2008) Relationships between alpha diversity of plant species in bloom and climatic variables across an elevation gradient. Int J Biometerol 52:353-366

Crimmins S, Dobrowski S, Greenberg J, Abatzoglou J, Mynsberge A (2011) Changes in climatic water balance drive downhill shifts in plant species' optimum elevations. Science 331:324-327

Čufar K, De Luis M, Saz M, Črepinšek Z, Kajfež-Bogataj L (2012) Temporal shifts in leaf phenology of beech (Fagus sylvatica) depend on elevation. Trees 26:1091-1100

Defila C, Clot B (2001) Phytophenological trends in Switzerland. Int J Biometerol 45:203-207

Elzinga J, Atlan A, Biere A, Gigord L, Weis A, Bernasconi G (2007) Time after time: flowering phenology and biotic interactions. Trends Ecol Evol 22:432-439

Everill P, Primack R, Ellwood E, Melaas E (2014) Determining past leaf-out times of New England's deciduous forests from herbarium specimens. Am J Bot 101:1293-1300

Fitter A, Fitter R, Harris I, Williamson M (1995) Relationships between first flowering date and temperature in the flora of a locality in central England. Funct Ecol 9:55-60

Forrest J, Thomson J (2010) Consequences of variation in flowering time within and among individuals of Mertensia fusiformis (Boraginaceae), an early spring wildflower. Am J Bot 97:38-48

Gaira K, Uppeandra D, Belwal O (2011) Potential of herbarium records to sequence phenological pattern: a case study of Aconitum heterophyllum in the Himalayas. Biodiver Conserv 20:2201-2210

Gezon Z, Inouye D, Irwin R (2016) Phenological change in a spring ephemeral: implications for pollination and plant reproduction. Glob Change Biol 22:1779-1793

Guyon D, Guillot M, Vitasse Y, Cardot H, Hagolle O, Delzon S, Wigneron J (2011) Monitoring elevation variations in leaf phenology of deciduous broadleaf forests from SPOT/ VEGETATION time-series. Remote Sens Environ 115:615-627

Inouye D (2008) Effects of climate change on phenology, frost damage, and floral abundance of montane wildflowers. Ecology 89:353-362

IPCC (2014) Climate change 2014: synthesis report. Contributions of working groups I, II, and III to the fourth assessment report of the intergovernmental panel on climate change. IPCC, Geneva

Jackson M (1966) Effects of microclimate on spring flowering phenology. Ecology 47:407-415

Kudo G, Ida T (2013) Early onset of spring increases the phenological mismatch between plants and pollinators. Ecology 94:2311-2320

Kudo G, Nishikawa Y, Kasagi T, Kosuge S (2004) Does seed production of spring ephemerals decrease when spring comes early? Ecol Res 19:255-259

Lambert A, Miller-Rushing A, Inouye D (2010) Changes in snowmelt date and summer precipitation affect the flowering phenology of Erythronium grandiflorum (glacier lily; Liliaceae). Am J of Botany 97:1431-1437

Lapointe L (2001) How phenology influences physiology in deciduous forest spring ephemerals. Physiol Plant 113:151-157

Lavoie C, LaChance D (2006) A new herbarium-based method for reconstructing the phenology of plant species across large areas. Am J Bot 93:512-516 
Lenoir J, Gégout J, Marquet P, De Ruffray P, Brisse H (2008) A significant upward shift in plant species optimum elevation during the 20th century. Sci 320:1768-1771

Livensperger C, Steltzer H, Darrouzet-Nardi A, Sullivan P, Wallenstein M, Weintraub M (2016) Earlier snowmelt and warming lead to earlier but not necessarily more plant growth. AoB Plants 8:plw021.

Matthews E, Mazer S (2016) Historical changes in flowering phenology are governed by temperature $\mathrm{x}$ precipitation interactions in a widespread perennial herb in western North America. New Phytol 210:157-167

McKinney A, CaraDonna P, Inouye D, Barr B, Bertelsen C, Waser N (2012) Asynchronous changes in phenology of migrating Broad-tailed Hummingbirds and their earlyseason nectar resources. Ecology 93:1987-1993

Memmott J, Craze P, Waser N, Price M (2007) Global warming and the disruption of plant-pollinator interactions. Ecol Lett 10:710-717

Miller-Rushing A, Inouye D (2009) Variation in the impact of climate change on flowering phenology and abundance: an examination of two pairs of closely related wildflower species. Am J Bot 96:1821-1829

Miller-Rushing A, Primack R (2008) Global warming and flowering times in Thoreau's Concord: a community perspective. Ecology 89:332-341

Miller-Rushing A, Primack R, Primack D, Mukunda S (2006) Photographs and herbarium specimens as tools to document phenological changes in response to global warming. Am J of Botany 93:1667-1674

Morin RS, Cook GW, Barnett CJ, Butler BJ, Crocker SJ, Hatfield MA, Kurtz CM, Lister TW, Luppold WG, McWilliams WH, Miles PD, Nelson MD, Perry CH, Piva RJ, Smith JE, Westfall JA, Widmann RH, West Woodall CW, Forests Virginia (2013) Resource Bulletin NRS-105. U.S. Department of Agriculture, Forest Service, Northern Research Station, Newtown Square, PA, p 128

Motten A (1986) Pollination ecology of the spring wildflower community of a temperate deciduous forest. Ecol Monogr $56: 21-42$

Park I, Schwartz M (2015) Long-term herbarium records reveal temperature-dependent changes in flowering phenology in the southeastern USA. Int J Biometeorol 59:347-355

Petanidou T, Kallimanis A, Sgardelis S, Mazaris A, Pantis J, Waser N (2014) Variable flowering phenology and pollinator use in a community suggest future phenological mismatch. Acta Oecologica 59:104-111

Primack R, Miller-Rushing A (2012) Uncovering, collecting, and analyzing records to investigate the ecological impacts of climate change: a template from Thoreau's Concord. Bioscience 62:170-181

Primack D, Imbres C, Primack R, Miller-Rushing A, Del Tredici P (2004) Herbarium specimens demonstrate earlier flowering times in response to warming in Boston. Am J Bot 91:1260-1264

Rafferty N, Ives A (2011) Effects of experimental shifts in flowering phenology on plant-pollinator interactions. Ecol Lett 14:69-74

Robbirt K, Davy A, Hutchings M, Roberts D (2011) Validation of biological collections as a source of phenological data for use in climate change studies: a case study with the orchid Ophrys sphegodes. J Ecol 99:235-241

Root T, Price J, Hall K, Schneider S, Rosenzweig C, Pounds J (2003) Fingerprints of global warming on wild animals and plants. Nature 421:57-60

Ruxton G (2006) The unequal variance t-test is an underused alternative to Student's t-test and the Mann-Whitney U test. Behav Ecol 17:688-690

Shetler S, Wiser S (1987) First flowering dates for springblooming plants of the Washington, DC, area for the years 1970 to 1983. Proc Biol Soc Washington 100:993-1017

Strausbaugh P, Core E (1978) Flora of West Virginia. Seneca Books, Grantsville

USA-NPN National Coordinating Office (2012) USA-NPN plant and animal phenophase definitions. https://www. usanpn.org/files/shared/files/USA-NPN_Phenophase_ defs-report_FINAL.pdf. Accessed 8 Feb 2017

Williams C, Menne M, Vose R, Easterling D (2007) United States historical climatology network monthly temperature and precipitation data. Carbon Dioxide Information Analysis Center, Oak Ridge National Laboratory, US Department of Energy, Oak Ridge, Tennessee, USA. https://cdiac. ornl.gov/epubs/ndp/ushen/ushcn.html. Accessed 8 Feb 2017

Publisher's Note Springer Nature remains neutral with regard to jurisdictional claims in published maps and institutional affiliations. 